\title{
THE DIFFERENCE PATTERN OF SUCCESSION BETWEEN SECOND GENERATION AND THIRD GENERATION FAMILY BUSINESS IN INDONESIA (A REVIEW OF THE MEDIUM-SIZE FAMILY BUSINESS)
}

\author{
Christina Whidya Utami \\ Lecturer of International Business Management Program \\ Ciputra University Surabaya
}

\begin{abstract}
The purpose of this study is to find out whether there are differences in the pattern of succession between the second and third generation of family business in Indonesia. Research design/methodology/approach: a cross sectional and comparative research design were used in this study and the data survey was conducted to 41 respondents from the secondgeneration group and 48 respondents from the third-generation group of family business; the businesses have been run for 5 to 50 years and were categorized as medium-sized family business. The study uses multiple regression test via SPSS to test the hypothesis. Findings: in family businesses led by second-generation successors, only the personality system affects the family business succession. On the other hand, in family businesses led by third-generation successors, personality, ownership, family, and management system variables affect the success of the family business. Meanwhile, the family system is not found to affect the family business succession. Research limitation/implication: this study investigates the pattern of succession in family businesses, including the personality system, ownership system, family system, and management system. This study suggests a solution in the regeneration process of a family business in order to maintain the continuity of the business. Limitations: There are some biases found on family's perspective of the assessment, and the study only focuses on medium-sized family businesses. Practical implications: the right amount of focus on the pattern of succession will help the second and third generation of the family to manifest business succession. Exploring the second and the third-generation perspectives regarding their succession pattern is the key to maintain the continuity of the family business. Originality/value: this study offers a pattern of succession from various perspectives, includ-
\end{abstract}

*Corresponding Author.

e-mail: whidyautami@ciputra.ac.id 
ing personal, ownership, family, and management as well as the relationship to the long-term success of the family business.

Keywords: family business succession, personality system, ownership system, family system, management system, the success of family business

\section{INTRODUCTION}

According to a survey done by PWC (Price Water Cooper) in 2014 regarding family businesses, more than $95 \%$ of businesses in Indonesia are owned by families while in South East Asia, $60 \%$ of publicly listed companies (Tbk.) are family companies. Data obtained by Family Firm Institute (2015) shows that twothirds of all companies in the world are family businesses. Looking from the perspective of labor absorption, 50-80\% of employment in the majority of countries in the world comes from family businesses (European Family Business, 2012 in Utami et al., 2017). In China, 70\% of companies are family owned companies (Martin, 2017 in Lily \& Marua, 2014). In the United States, a total of 24 million family businesses absorb 62\% of the existing workforce and contribute to $64 \%$ of the total Gross Domestic Product (GDP). The Jakarta Consulting Group shows that $88 \%$ of national companies are family businesses. Based on the data from Indonesian National Economic Census (SUSENAS) in 2011, there were 50,363,980 companies, in which 92,65\% of them are family businesses. With all these facts in hand, maintaining a family business in an important factor and thus, efforts that are worth doing are planning a process of regeneration or succession well (Utami et al., 2017).

An effective process of succession is crucial in determining the continuity of the family business (Buang et al., 2013; Carlock \& Ward, 2005) and problems related to succession becomes the key factor and continue to be a threat towards the success and the continuity of the family business (Brenes et al., 2011; Buang et al., 2013; Norita et al., 2010). According to Carlock and Ward (2005), planning a succession is about pooling talented people who can contribute their special skills and abilities towards the business' success, by trying to achieve the company's short-term and long-term goals. Ineffective process of succession may bring serious implications, not only for the family members and business partners, but also for the country's economic development (Buang et al., 2013). 
Furthermore, Buang et al. (2013) stated that family businesses also face internal conflicts between the family members. Strategic decisions, standard controls, and operation management activities are often handled only by the owner, so their perspective on the level of professionalism, interest on risk, and achievement of growth often do not meet the professional standards as well as business management standard in general (Jayaram et al., 2014).

A number of studies have focused on finding factors or systems that support and effectively implement succession. An effective plan of succession must be able to identify potential candidates (Taylor and McGraw, 2004), train them to be competent in order to create a smooth transition and increase the survival rate of the family business (Ibrahim et al., 2003). According to Handler (1991), the level of responsibility and condition outside the family business is also important to create an effective plan of succession. Transition within the family business is also affected by external factors, such as market demand, market condition, economic condition, buying offers from potential buyers, and pressure to complete external loans (Morris et al., 1996). Morris et al. (1996) also stated that the level of preparation of heirs and the relationship between family and business members contributed to an effective succession in a family company. A positive relationship between each family member becomes another important factor that should be constantly built and maintained (Bachkaniwala et al., 2001). Family business will be able to compete globally if they take advantage of trust among the family members who have invested since the beginning of the business (Carlock and Ward, 2001). Positive relationship and communication between family members are needed for effective succession (Helin and Jabri, 2016; Pyromalis and Vozikis, 2009). As stated by Handler (1990) in Seon-Hong 'Sun'Joo (2016), with an understanding about the importance of studying family business, nowadays a lot of literature concentrate on family involvement in ownership, governance, and management of the succession process.

Based on Utami et al. (2017), there are two factors that should be considered in implementing succession in family business, which are: planning and pattern of succession. Pattern of succession in the management of family business can be analyzed through personality system, family system, ownership system, and management system. Pattern of succession in family businesses includes personality system, family system, ownership system, and management 
system, and these influence the efforts needed to maintain the succession of the family business. On the other hand, pattern of success in an older family business will have more complex mechanisms because it involves generations far from the founder of the family business. Kalra and Gupta (2014) stated that only around $30 \%$ of family businesses can survive until the second generation, while only $12 \%$ of family business have survived until the third generation. Kalra and Gupta (2014) further stated that only 3\% of family businesses are able to survive the transition of the fourth generation and $70 \%$ of family businesses in small and medium enterprises (SMEs) must eventually be destroyed due to lack of successful planning.

According to the background information above, the research problem can be formulated as follows: are there different success patterns from the second and the third generation that leads to the success of family businesses in Indonesia.

\section{LITERATURE REVIEW}

\subsection{Pattern of success in Family Businesses}

According to Baur (2014), a pattern of success consists of 4 components, which are personality system, family system, ownership system, and management system.

\subsubsection{Personality System}

A model of entrepreneurial career dynamics in sociology (Carroll and Mosakowski, 1987) and economy (Evans and Leighton, 1989) as quoted in Mattias Norqvist et al. (2012) stated that a literature review of the personal system requires a successor to have personal abilities, namely entrepreneurial orientation, leadership, and the ability to take responsibility. In particular, the entrepreneurial "process model" (Eckhardt et al., 2006; Van de Ven and Engelman, 2004) considers succession as a selected event from the successors in the family business (Carroll, 1984) and succession as an explanatory mechanism in which founders can "monetize' their performance (DeTienne and Cardon, 2012). Thus, the success pattern of the personality system is characterized by an individual's 
abilities within the family business to innovate, to be proactive, and the ability to take risks as a characteristic of an entrepreneur and the ability to be a leader. In this study, personality system will be viewed from the aspects of Successor Qualification, Entrepreneurial Orientation, Willingness to Take Responsibility, Personality Traits, Management and Leadership Skills with details as follow; 1) Successor Qualification. Effective successors have a comprehensive educational background that is relevant to the business and continue to invest in their personal development. Effective successors will pursue intensive trainings from within the business and outside the field. 2) entrepreneurial Orientation. Effective successors have high business orientation. Their characteristics include resilience, risk-taking management, fast, and flexible. They take initiatives to create something new by adding value to what has been around. 3) Willingness to Take Over Responsibility. Effective successors show that they are willing to take over responsibility based on their own motivation and early involvement in running the family business. 4) Personality traits, Management and Leadership Skills. Effective successors show courtesy and confidence. In addition, effective successors should be able to foster positive relationships with the older generation. They are willing to apply knowledge on management and leadership skills from older generations.

\subsubsection{Family System}

Researchers generally agree that the aspect of family involvement makes family business different than other non-family business model (Miller \& Rice, 1967 in Aldrich \& Cliff, 2003). Family business is seen as a unique combination of family and business (Gersick, Davis, McCollom, Hampton \& Lansberg, 1997). Family business is different because it is based on the activities of each family member, regardless of whether they are directly or indirectly involved in the family business. Furthermore, the important aspect of family business is their kinship and positive effects on the recognition of entrepreneurial opportunities (Aldrich \& Cliff, 2003).

However, the closeness and kinship in family business often lead to conflict. Davis and Harveston (2011) conducted a study to understand inter-generational conflicts in family companies and investigated the influence of family members 
regarding the level and the frequency of potential conflicts resulting from family relationships. A high level of interaction between family members strengthen the level of conflicts between all generations and/or groups involved. The more family members working in the company, the higher the potential for conflict happening to all generations involved. Which may be caused by the presence of different perspectives on goals and actions. However, family members that are not actively involved in daily business operations can play an important role in promoting reconciliation. Social interaction between family members also increase the intensity of conflict. This can happen due to the lack of boundaries between family and business, which allows personal disputes or conflicts to be brought into professional interaction.

Conflict is the biggest way to destroy a family business (Hennerkes, 2005 page. 58). This can especially occur during the succession process when emotions and challenges that need to be overcome become the main hindering factors instead. A psychological spectrum includes interpersonal relationships between predecessors and successors, the imaginary line between family and business, and the hierarchy that creates knowledge and risky decision as the triggers for conflicts to emerge.

In this research, the family system will be viewed from 3 aspects: family culture and value, family dynamic and conflicts, family trust and appreciation, with the following details: (1) Family Culture and Value. Effective successors uphold and understand the culture adopted by the family and also adhere to the values inherited from the previous generation. They must place the business as their first priority. They should decide what they want to achieve in the company. (2) Family Dynamics and Conflicts. Effective successors recognize the possibility of having different opinions within the family. 3) Family Trust and Appreciation. Effective successors should believe in every member of the family. This is also rooted in the fact that they share basic values with the older generation.

\subsubsection{Ownership System}

Succession is a multidimensional process that can be affected by big variables. Most literatures in family business study about ruling related factors, most of which refer to the founders' reluctance to plan a succession process 
regarding related issues, including a strong sensitivity to business relations, fear of retirement, death, and lack of interest in other factors (Cabrera-Sua'rez et al., 2001; Handler, 1990; Lansberg and Astrachan, 1994; Levinson, 1971). Other related factors focus on successive business skills, managerial abilities, knowledge of the company's operations, and the tendency of attitude towards running a business (Barach and Ganitsky, 1995).

In this study, Ownership System will focus on the aspects of: Governance and Controlling Power, Transfer of Capital and Estate Planning, and Performance and Assessment; detailed as follows: (1) Governance and Controlling Power. Effective successors use the same rules, structure, and governance as those managed by their predecessors. They must be able to manage the business based on the family's mutual trust and control the balance of between family and business interest. (2) Transfer of Capital and Estate Planning. Effective successors may inherit business operations. Non-operative assets are excluded from the business to increase the equality of family assets and to maintain the integrity of the family. (3) Performance and Assessment. Effective successors must show a good working performance and judgement. They must also have higher hopes towards their business performance than their predecessors. This will lead a better business performance.

\subsubsection{Management System}

One of family business models where the model follows close systematic perspective (Whiteside and Brown, 1991 in Rautiainen Marita et al., 2012) conceptualize family business as a dual system, which are the family and business perspective. Davis and Stern (1988) stated that an increase in ownership and control can be done via an integrated system perspective, which describes a series of process and mechanism that decide and control the interaction between the business and family system. Habbershon and Pistrui (2002) and Rautiainen Marita et al. (2012) presented a management system approach to show performance that links to resources and capabilities produced in the family system regarding their potential to build transgenerational wealth. Family business is unique due to the family's involvement in ownership, governance, management, and sharing of the same vision. 
In this research, the Management System will focus on the aspects of Strategy Development and Business Management, Company Goals and Strategy Implement, Transfer of Leader, Transfer of Leadership Role, and Leadership Style and Organization Culture, detailed as follows: (1) Strategy Development and Business Management. Effective successors should have a good development and management strategy for the company. They have creative ideas that can later be used to develop the family business and to develop the management system of the business. (2) Company Goals and Strategy Implement. Effective successors' goal is to bring the family business towards a better and more advanced direction. They must be ready to face obstacles that might occur in the family business. (3) Transfer of Leader. Effective successors have a clear map in terms of succession and the transfer of leadership role. It becomes very important for the successor to try to think far ahead regarding the family business. (4) Transfer of Leadership Role. Effective successors must understand the arrangements for clear signs of leadership transition. Usually, the arrangements involve celebrations and ceremonies. Effective successors are supported by the seniors that will leave the company. However, effective successors consider how difficult it might be for the seniors to leave and try to find alternative strategies to involve the seniors in the business after the transition. (5) Leadership Style and Organization Culture. Effective successors strive to advance the business as an attractive workplace. Their leadership must prioritize the implementation of tasks, cooperative relations, and goals to be achieved, as well as understand the organization culture in the family business.

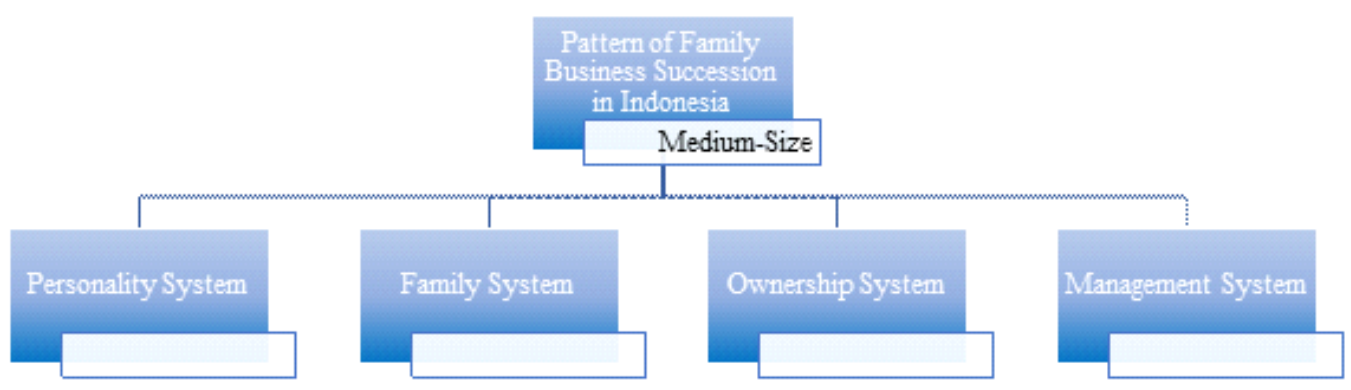

Figure 1 Systematic process of Patter of Medium-Size Family Business Succession in Indonesia 


\subsection{Relationship between the Succession and the Success of a Family Business}

Ineffective succession process has serious implications, not only for the family members and business partners, but also for the country's economic development (Buang et al., 2013). Kim and Gao (2012) identified that the interaction between family, business, and family members creates systemic conditions and constituencies that affect the performance of the family business in the long run (Kim and Gao, 2012). Chu (2011) in Mozhdeh Mokhber et al. (2017) found that small family businesses show better business performances due to closer family ties between family members, which further facilitates communication between family members. Chu (2011) in Mozhdeh Mokhber et al. (2017) further revealed that older companies show worse performance because of the bureaucracy in the family business and the refusal to effectively change according to the environment and, at the same time, face difficulties in the regeneration process. Thornhill and Amit (2003) in Mozhdeh Mokhber et al. (2017) support this fact by stating that discrepancies between resources and abilities and demand from the competitive environment are the reasons for the failure of older family businesses. Therefore, family business succession is really important (Boyd et al., 2015) as it can lead to the preparation of heirs and at the same time to support the sustainability of the family business.

The level of preparation of the heirs is closely related to the family business' performance. Ibrahim and Ellis (1994) in Mozhdeh Mokhber et al. (2017) identified that family business should emphasize the importance of the successor's education to enable the company to stay on the market. Knowledge and skills acquired in colleges or universities can be applied in a number of business situations (Sardeshmukh and Corbett, 2011). In terms of the age of the successor, Brockmann and Simmonds (1997) argued that the success of the family business is related to age. Older owners are more likely to have more experience in business; hence it contributes to the success of the family business. It is important for successors to have work experience, especially outside the family business, to ensure the success and the continuity of the family business (Luke, 1996; Masuo et al., 2011 in Mozhdeh Mokhber et al., 2017). Having experience outside the family business is seen as a valuable asset because the successors usually gain lots of experience from other companies (Barach and Gantisky, 1995 in Mozhdeh Mokhber et al., 2017). 
Based on the literature review above, this study has several hypotheses, described as follows:

H1: There is a significant influence of the second-generation succession pattern on the success of family business in Indonesia.

$\mathrm{H} 2$ : There is a significant influence of the third-generation succession pattern on the success of family business in Indonesia.

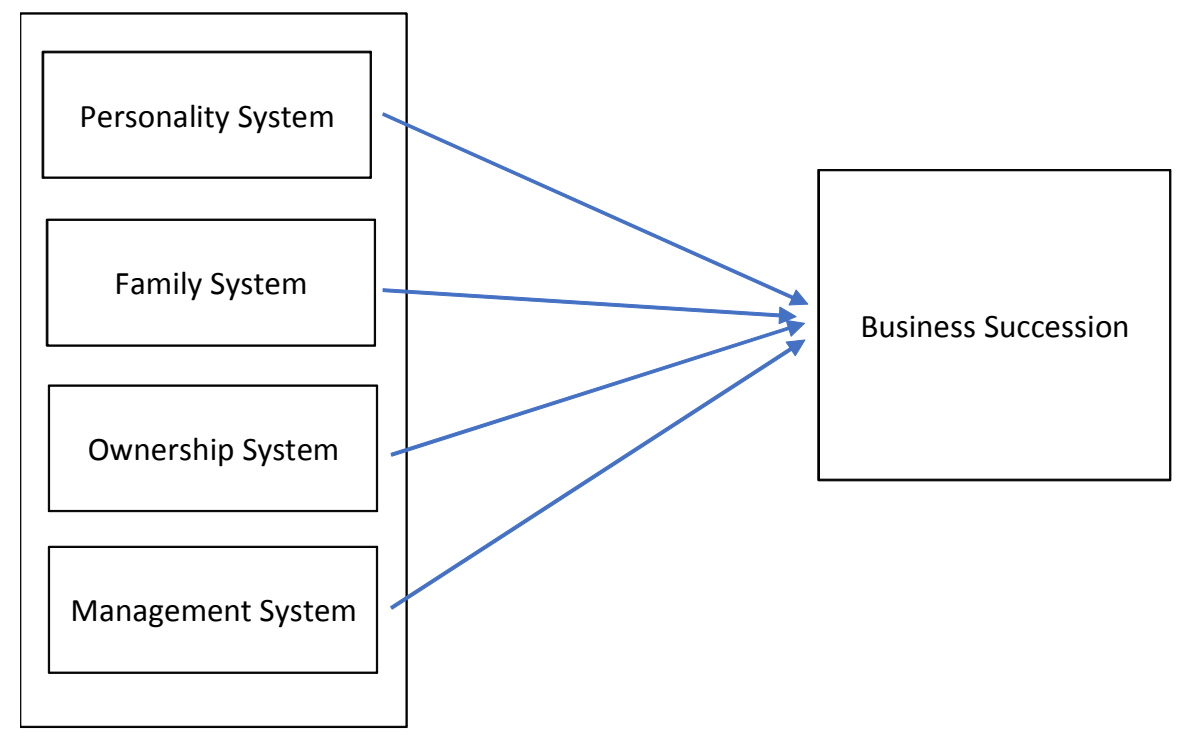

Figure 2 Research Model of the Business Succession Pattern in the Second-Generation and the Third-Generation of Family Businesses

\section{METHODOLOGY}

\subsection{Population, Sample Group, and Empirical Setting}

There is no official systematic process that shows the number of middle-size family businesses in Indonesia, so the researcher chose to use convenience and snowball sampling techniques. Data is collected though questionnaires distributed to successors of family businesses in various regions in Indonesia. The researcher also collected data from several referrals recommended by previous respondents. In the end, one hundred questionnaires are collected from family businesses; the family businesses qualifications are based on the turnover criteria 
and the number of employees in the category of medium-sized business group. Of the hundred questionnaires, forty-one samples came from the leaders of second-generation family businesses and forty-eight samples came from thirdgeneration family businesses, while the remaining eleven samples did not meet the qualification.

Respondents answered the questions from a scale of 1-5. Previously, the questionnaire has been validated using the Pearson correlation test shown in Table 1, while the reliability test was carried out using a Cronbach Alpha test, resulting in a value of 0.742 .

Table 1 Research Reliability Test

\begin{tabular}{|c|c|c|c|c|c|c|}
\hline & & PERSONSYS & OWNERSYS & FAMSYS & MANAGSYS & BUS_SUCCESSION \\
\hline \multirow{4}{*}{ PERSONSYS } & $\begin{array}{l}\text { Pearson } \\
\text { Correlation }\end{array}$ & 1 & $.606^{* *}$ & $.271^{*}$ & $.491^{\text {stz }}$ & $.287^{* 21}$ \\
\hline & Sig. (2-tailed) & & .000 & .010 & .000 & .006 \\
\hline & $\mathrm{N}$ & 30 & 30 & 30 & 30 & 30 \\
\hline & $\begin{array}{l}\text { Pearson } \\
\text { Correlation }\end{array}$ & $.606^{* *}$ & 1 & $.318^{* n}$ & $.675^{* 3 *}$ & $.351^{* 3 *}$ \\
\hline \multirow{2}{*}{ OWNERSYS } & $\begin{array}{l}\text { Sig. (2-tailed) } \\
\mathrm{N}\end{array}$ & $\begin{array}{l}.000 \\
30\end{array}$ & 30 & $\begin{array}{l}.002 \\
30\end{array}$ & $\begin{array}{l}.000 \\
30\end{array}$ & $\begin{array}{c}.001 \\
30\end{array}$ \\
\hline & $\begin{array}{l}\text { Pearson } \\
\text { Correlation }\end{array}$ & $.271^{*}$ & $.318^{* * *}$ & 1 & $.354^{* * *}$ & $.351^{* *}$ \\
\hline \multirow{2}{*}{ FAMSYS } & Sig. (2-tailed) & .010 & .002 & & .001 & .001 \\
\hline & & 30 & 30 & 30 & 30 & 30 \\
\hline \multirow{3}{*}{ MANAGSYS } & $\begin{array}{l}\text { Pearson } \\
\text { Correlation }\end{array}$ & .491 & .675 & .354 & & .333 \\
\hline & $\begin{array}{l}\text { Sig. (2-tailed) } \\
\mathrm{N}\end{array}$ & $\begin{array}{l}.000 \\
30\end{array}$ & $\begin{array}{c}.000 \\
30\end{array}$ & $\begin{array}{c}.001 \\
30\end{array}$ & 30 & $\begin{array}{c}.001 \\
30\end{array}$ \\
\hline & Pearson & $.287^{* * *}$ & $.351^{* *}$ & $.351^{* *}$ & $.333^{* *}$ & 1 \\
\hline \multirow[t]{2}{*}{ BUS_SUCCESSION } & Sig. (2-tailed) & .006 & .001 & .001 & .001 & \\
\hline & $\mathrm{N}$ & 30 & 30 & 30 & 30 & 30 \\
\hline
\end{tabular}

$* *$. Correlation is significant at the 0.01 level (2-tailed).

*. Correlation is significant at the 0.05 level (2-tailed).

\subsection{Measures}

The instrument to measure this study are acquired from Baur (2014), Utami et al. (2017), and Utami (2017). An effective successive pattern consists of 4 components, which are personality system, family system, ownership system, and management system. a) The personality System includes: Successor qualification, Entrepreneurial Orientation, Willingness to take over responsibility, personality traits, and management and leadership skills. B) The ownership system includes: 
governance and strength control, capital transfer, and performance. C) The family system includes: family values and culture, dynamics, and conflict and trust/ appreciation. D) The management system includes: strategy development, strategy implementation, leadership transfer, and organizational culture. The instruments of family business success are developed based on Mozhdeh Mokhber et al. (2017). The complete instruments can be seen in Appendix 1.

\subsection{Data Analysis}

Analysis was done by SPSS. Bias-corrected 95 percent confidence intervals were obtained using 10,000 bootstrap (re) samples. An F-test was used to compare the full model against a base model. The t-test was used to know whether the independent variables, which are personality system, family system, ownership system, and management system, have a significant effect on the dependent variable, which is the success of family business.

\section{a) F-test and T-test on second-generation succession pattern on the success of family business in Indonesia}

According to the F-test, there is goodness of fit across all independent variables, which are personality system, family system, ownership system, and management system towards the success of family business. However, the T-test shows that only the personality system has a significant effect on the success of family business. The other variables, family system, ownership system, and management system do not show any significant effect on the success of family business.

Table $2 \mathrm{R}$ and $\mathrm{R}$ Square on the Second-Generation

\begin{tabular}{|c|c|c|c|c|}
\hline Model & $\mathrm{R}$ & R Square & Adjusted R Square & $\begin{array}{c}\text { Std. Error of the } \\
\text { Estimate }\end{array}$ \\
\hline 1 & $.581^{\mathrm{a}}$ & .338 & .276 & .43324 \\
\hline
\end{tabular}

a. Predictors: (Constant), MANAGSYS, FAMSYS, PERSONSYS, OWNERSYS 
Christina Whidya Utami / The Difference Pattern of Succession between Second Generation and Third Generation Family Business in Indonesia (A Review of the Medium-Size Family Business)

Table 3 F-Test on the Second Generation

\begin{tabular}{|l|c|c|c|c|c|}
\hline \multicolumn{1}{|c|}{ Model } & Sum of Squares & df & Mean Square & F & Sig. \\
\hline \multicolumn{1}{|c|}{ Regression } & 4.117 & 4 & 1.029 & 5.483 & $.001^{\mathrm{b}}$ \\
Residual & 8.071 & 43 & .188 & & \\
Total & 12.188 & 47 & & & \\
\hline
\end{tabular}

a. Dependent Variable: BUS_SUCCESSION

b. Predictors: (Constant), MANAGSYS, FAMSYS, PERSONSYS, OWNERSYS

Table $4 \mathrm{t}$-Test on the Second Generation

Coefficients $^{\mathrm{a}}$

\begin{tabular}{|c|c|c|c|c|c|c|}
\hline & \multirow[t]{2}{*}{ Model } & \multicolumn{2}{|c|}{$\begin{array}{l}\text { Unstandardized } \\
\text { Coefficients }\end{array}$} & $\begin{array}{l}\text { Standardized } \\
\text { Coefficients }\end{array}$ & \multirow[t]{2}{*}{$\mathbf{t}$} & \multirow[t]{2}{*}{ Sig. } \\
\hline & & B & Std. Error & Beta & & \\
\hline \multirow{5}{*}{1} & (Constant) & 1.035 & .770 & & 1.344 & .186 \\
\hline & PERSONSYS & .465 & .218 & .371 & 2.135 & .039 \\
\hline & OWNERSYS & .049 & .229 & .038 & .214 & .831 \\
\hline & FAMSYS & .136 & .106 & .186 & 1.278 & .208 \\
\hline & MANAGSYS & .150 & .199 & .128 & .754 & .455 \\
\hline
\end{tabular}

a. Dependent Variable: BUS_SUCCESSION

b) F-test and T-test on third-generation succession pattern on the success of family business in Indonesia.

Based on the F-test, there is goodness of fit between all independent variables, which are personality system, family system, ownership system, and management system towards the success of family business. In addition, the t-test shows that all independent variables, which are personality system, family system, ownership system, and management system, have a significant positive effect toward the success of family business.

Table $5 \mathrm{R}$ and $\mathrm{R}$ Square on the Third-Generation

Model Summary

\begin{tabular}{|c|c|c|c|c|}
\hline Model & R & R Square & Adjusted R Square & $\begin{array}{c}\text { Std. Error of the } \\
\text { Estimate }\end{array}$ \\
\hline 1 & $.681^{\mathrm{a}}$ & .464 & .414 & .42399 \\
\hline
\end{tabular}

a. Predictors: (Constant), MANAGSYS, FAMSYS, PERSONSYS, OWNERSYS 
Table 6 F-Test on the Third Generation

ANOVA $^{\mathrm{a}}$

\begin{tabular}{|l|c|c|c|c|c|}
\hline \multicolumn{1}{|c|}{ Model } & Sum of Squares & df & Mean Square & F & Sig. \\
\hline \multirow{2}{*}{1 Regression } & 6.687 & 4 & 1.672 & 9.299 & $.000^{\mathrm{b}}$ \\
Residual & 7.730 & 43 & .180 & & \\
Total & 14.417 & 47 & & & \\
\hline
\end{tabular}

a. Dependent Variable: BUS_SUCCESSION

b. Predictors: (Constant), MANAGSYS, FAMSYS, PERSONSYS, OWNERSYS

Table 7 t-Test on the Third Generation

CoeCoefficients ${ }^{\mathrm{a}}$

\begin{tabular}{|c|c|c|c|c|c|c|}
\hline & \multirow[t]{2}{*}{ Model } & \multicolumn{2}{|c|}{$\begin{array}{c}\text { Unstandardized } \\
\text { Coefficients }\end{array}$} & \multirow{2}{*}{$\begin{array}{c}\begin{array}{c}\text { Standardized } \\
\text { Coefficients }\end{array} \\
\text { Beta }\end{array}$} & \multirow[t]{2}{*}{$\mathbf{t}$} & \multirow[t]{2}{*}{ Sig. } \\
\hline & & B & Std. Error & & & \\
\hline \multirow{5}{*}{1} & (Constant) & 4.364 & 1.291 & & 3.380 & .002 \\
\hline & PERSONSYS & 1.234 & .305 & .538 & 4.043 & .000 \\
\hline & OWNERSYS & 1.320 & .316 & .872 & 4.180 & .000 \\
\hline & FAMSYS & .315 & .129 & .288 & 2.448 & .019 \\
\hline & MANAGSYS & .439 & .291 & .284 & 2.512 & .038 \\
\hline
\end{tabular}

a. Dependent Variable: BUS_SUCCESSION

\section{RESPONDENT DESCRIPTION AND DISCUSSION}

\subsection{Respondent Description}

Of the one-hundred questionnaires distributed, only eighty-nine respondents were eligible for further analysis. The description is as follows: based on the level of education, as much as five percent of the respondents have learning experience and have graduated from universities/ schools abroad, while ninety-five percent of them have the opportunity to study in and have graduated from local universities or school. Examining the data from the level of education, thirty percent of the respondents are S2 (master) graduates, thirty-eight percent of them are S1 (bachelor) graduates, and the remaining forty-two percent are high school graduates. From the age of the company, the data shows that fifty-six percent of the businesses has run for over twenty years, while forty-four percent of them have run between five to twenty years. Looking at the gender of the 
successors, twenty-seven percent of successors are women and seventy-three percent of them are men. From all of the twenty-seven percent of women successors, only twenty-one percent of them became successors in secondgeneration, and the remaining seventy-nine percent became successors in the third-generation.

\subsection{Discussion}

This study focuses to analyze the different effects of personality, family, ownership, and management system on the success of second and third generation family business in Indonesia.

a) In family businesses that are led by second-generation successors, the study found that only personality system has a positive significant effect towards the success family business.

This finding is in line with the opinion from Mattias Norqvist et al. (2012) which stated that the successors' personality characteristic will be very prominent in family businesses that have just gone through the succession process from the first generation to the third generation. Mattias Norqvist et al. (2012) stated that a review of the personality system requires a successor to have personal abilities that include entrepreneurial orientation, leadership, and the ability to take responsibility as the focus of succession process. In particular, the entrepreneurial process model (Eckhardt et al., 2006; Van de Ven and Engelman, 2004) considers succession as a selection of events among family enterprise successors (Carrol, 1984) and this succession process as an explanatory mechanism in which the predecessor can "monetize" their performance (DeTienne and Cardon, 2012)

b) In family businesses lead by third-generation successors, the study found that all independent variables, which are personality, family, ownership, and management system, have a positive significant effect on the success of family business.

This study shows that the pattern of success in third-generation successors is more complex as the businesses need more resources to support the success of the family business. A supportive personality system is insufficient, and has broadened into family, ownership, and management system. Aligning with the 
findings of Seon Hong Suun Joo (2016), strategic plans will help strengthen the family business and improve the business life. Strategic planning within a family business is definitely different than in other types of business, such as corporations or non-profit businesses, because family businesses must deal with the family and business problems at the same time. Thus, success pattern for the third generation is not only about the personality of the successors and the family business, but also about the successors' management and managerial capabilities. This finding is supported by respondents' descriptions about their education background where five percent of respondents have studied and/or graduated from universities overseas, and ninety-five percent have studied and/or graduated from universities in Indonesia. Seeing from the respondents' education level, thirty percent of respondents graduated with a master's degree (S2), thirty-eight percent graduated from bachelor's degree (S1), and forty-two percent graduated from high school. This shows that the successor's educational background is an important aspect to be considered before being given the responsibility to carry out the task of maintaining the sustainability of the family business.

Furthermore, Mozhdeh Mokhber et al. (2017) stated that older businesses often show worse performance because of the bureaucracy in the family companies and their refusal to change according to the environment. Thronhill and Amit (2003) in Mozdeh Mokhber et al. (2017) supported this fact by stating that the mismatch between resources and capabilities and competitive demands from the environment is the main reason why older family businesses are more likely to fail. This condition reinforces the need for third-generation successors the be better equipped with the ability to deal with family conflicts and managerial management in terms of ownership and management system. Habbershon and Pistrui (2002) and Rautiainen Marita et al. (2012) presented the management system to show types of performances that link to resources and abilities within the family system to create transgenerational wealth and, at the same time, the sustainability and the long-term success of the family business. 


\section{MANAGERIAL IMPLICATION}

The findings of this study present an invaluable understanding regarding family businesses and the importance of the level of successor preparation and the relationship between personality, family, ownership, and management systems on business performance. These aspects can help family businesses to better understand how they can improve their business succession by emphasizing more on the key factors that affect succession plan. Therefore, it is important to focus on preparing the successors' performance, starting from their education, training outside the business, reinforcement of motivation, and self-perception. In addition, successors should have a good relationship with other family members in terms of trust and communication, as well as giving them appreciation, courage to take responsibility, managerial abilities, appropriate decision making, ability to control, understanding of the family culture and values, conflict management skills, innovative and creative traits, and risk calculation skills. All are intended so that the company may achieve better business performance.

For this reason, according to Mozdeh Mokhber et al. (2016), there is a need for family businesses to allocate budgets to ensure successors' readiness to take over the business and to reduce obstacles from other family members that can disrupt the transition process. To develop healthy and fulfilling relationships at work and at home, family and business members must be responsible, in every way, to show their genuine interest in the aspiration and goals of the others, to treat everybody with respect, and to be an integrated business partner.

Looking at family relationship, communication should always be encouraged because it is the main tool to resolve differences, quarrels, competition, and misunderstanding. Trust in family relationships can be strengthened only if the family members are truly committed to communicate openly. During the succession process, consistency in high-quality communication is needed for adequate business exploration and for dealing with problems (Magasi, 2016). Interrelated and interdependent interactions between family members are the top priority to keep the family harmonious and the business prosperous. A healthy family dynamic must be present so that the relationship between family and business members remains strong. To have a decent family business, balance between relationship as family members and contractual relationship as business owner 
needs to be maintained; in addition, it is also important to constructively separate ownership issues from management issues.

For second-generation successors, aspects related to family, ownership, and management system must be prepared and considered. Given that second generation members are the generation who holds responsibility for the company's life cycle that might not be mature yet, the family might consider getting professional help to secure the success of their business. Whereas for thirdgeneration successor, all aspects related to personality, family, ownership, and management system must be considered because the company's life cycle requires more creative management to be able to extend the maturity cycle and to avoid a declining cycle.

\section{LIMITATION OF THE STUDY}

This study has several limitations. One of them is the bias of family's members own perspective on their assessment, and the scope of the scale of family business ventures that only focuses on medium-size businesses. The size of the business will surely have an impact on how the succession pattern runs and will also have a positive impact on the success of the family business.

\section{CONCLUSION}

Based on the results of this study that are supported by previous studies, it can be concluded that there is a need to raise family businesses' awareness about the importance of understanding the pattern of succession and its relationship to the success of the family business.

In family businesses lead by second-generation successors, only personality system affects the success of the family business. While on family businesses lead by a third-generation successor, personality, ownership, family, and management system have an effect towards the success of the family business. It is important for family businesses to adopt the most appropriate and effective succession plan to suit their choice of succession patterns, which includes personality, family, ownership, and management system, thus ensuring that the family business can be maintained and will survive in the global arena. 
A professional management for the family business, for both successors and their loving and caring family members, is needed. It will place every family member in a favorable position in the family business, and also develop the business and renew their business strategies. Thus, the next generation will be able to follow in the footsteps of their ancestors to expand their businesses and to bring greater success to the family business, and also to the country's' economy condition.

\section{REFERENSI}

Aldrich, H.E. \& Cliff, J. E. 2003. The Pervasive Effects of Family on Entrepreneurship.

Bachkaniwala, D., Wright, M. and Ram, M. 2001. Succession in South Asian Family Businesses in the UK. International Small Business Journal, Vol. 19, No. 4, pp. 15-27.

Barach, J.A. and Gantisky, J.B. 1995. Successful Succession in Family Business. Family Business Review, Vol. 8, No. 2, pp. 131-155.

Brenes, E.R., Madrigal, K. and Requena, B. 2011. Corporate Governance and Family Business Performance. Journal of Business Research, Vol. 64, No. 3, pp. 280-285.

Berent-Braun, M.M. and Uhlaner, L.M. 2012. Responsible Ownership Behaviors and Financial Performance in Family Owned Businesses. Journal of Small Business and Enterprise Development, Vol. 19, No. 1, pp. 20-38.

Brockmann, E.N. and Simmonds, P.G. 1997. Strategic Decision Making: the Influence of CEO Experience and Use of Tacit Knowledge. Journal of Managerial Issues, Vol. 9, No. 4, pp. 454-468.

Buang, N.A., Ganefri, G. and Sidek, S. 2013. Family Business Succession of SMEs and Post-Transition Business Performance. Asian Social Science, Vol. 9 No. 12, pp. 79-92.

Cabrera-Sua'rez, K. 2005. Leadership Transfer and the Successor's Development in the Family Frm. The Leadership Quarterly, 16(1), 71-96

Carlock, R.S. and Ward, J.L. 2005. Assuring a Healthy Business. In Family Business, Palgrave Macmillan, pp. 17-30. 
Carlock, R.S. and Ward, J.L. 2001. Strategic Planning for the Family Business: Parallel Planning to Unify the Family and Business. Macmilan: Palgrave.

Carroll, G. 1984. Dynamics of Publisher Succession in Newspaper Organizations. Administrative Science Quarterly, 29(1), 93-113.

Carroll, G., \& Mosakowski, E. 1987. The Career Dynamics of Self-Employment. Administrative Science Quarterly, 32(4), 570-589.

Chu, W. 2011. Family Ownership and Firm Performance Influence of Family Management, Family Control, and Firm Size. Asia Pacific Journal of Management, Vol. 28, No. 4, pp. 833-851

Davis, P.S. and Harveston, P.D. 1999. In the Founder's Shadow: Conflict in the Family Firm. Family Business Review, Vol. 12, No. 4, pp. 311-323.

Davis, P. and D. Stern. 1988. Adaptation, Survival, and Growth of the Family Business: An Integrated Systems Perspective. Family Business Review, 1(1): 69-84.

DeTienne, D.R. 2010. Entrepreneurial Exit as a Critical Component of the Entrepreneurial Process: Theoretical Development. Journal of Business Venturing, 25(2), 203-215.

Eckhardt, J., Shane, S., \& Delmar, F. 2006. Multistage Selection and the Funding of New Ventures. Management Science, 52(2), 220-232.

Gersick, K., Lansberg, I., Desjardins, M., \& Dunn, B. 1999. Stages and Transitions: Managing Change in the Family Business. Family Business Review, 12(4), 287-297.

Gersick, K., Davis, J., Hampton, M., and Lansberg, I. 1997. Generation to Generation: Life Cycles of the Family Business. Boston, MA: Harvard Business School Press.

Handler, W.C. 1991. Key Interpersonal Relationships of Next-Generation Family Members in Family Firms. Journal of Small Business Management, Vol. 29 No. 3, pp. 21-32.

Habbershon, T.G., Williams, M., and MacMillan, I.C. 2003. A Unified System Perspective of Family Performance. Journal of Business Venturing, Vol. 18 No. 4, pp. 451-465.

Handler, W.C. (1991), "Key interpersonal relationships of next-generation family members in family firms", Journal of Small Business Management, Vol. 29 No. 3, pp. 21-32. 
Helin, J. and Jabri, M. 2016. Family Business Succession in Dialogue: the Case of Differing Backgrounds and Views. International Small Business Journal, Vol. 34, No. 4, pp. 487-505.

Ibrahim, A.B. and Ellis, W.H. 1994. Family Business Management: Concepts and Practice. Dubuque, IA: Kendall/Huntg Publishing Company.

Ibrahim, A.B., Soufani, K., and Lam, J. 2003. Family Business Training: a Canadian Perspective. Education+Training, Vol. 45, Nos 8/9, pp. 474-482. Jayaram, J., Dixit, M., and Motwani, J. 2014. Supply Chain Management Capability of Small and Medium Sized Family Businesses in India: a Multiple Case Study Approach. International Journal of Production Economics, Vol. 147, pp. 472-485.

Kalra, N. and Gupta, S. 2014. Succession Planning in SMEs: an Empirical Analysis. International Journal of Research in Management and Social Science, Vol. 2, No. 2, p. 124.

Kim, Y. and Gao, F.Y. 2012. Does Family Involvement Increase Business Performance? Family Longevity Goals Moderating Role in Chinese Family Firm. Journal of Business Research, Vol. 66, No. 2, pp. 265-274.

Lansberg, I. \& Astrachan, J. 1994. Inûuence of Family Relationships on Succession Planning and Training: The Importance of Mediating Factors. Family Business Review, 7(1), 39-59.

Levinson, H. 1971. Conûicts that Plague Family Business. Harvard Business Review, Vol. 49, Nos 3/4, pp. 91-98

Luke, S.T.K. 1996. Success in Hong Kong: Factors Self-Reported by Successful Small Business Owners. Journal of Small Business Management, Vol. 34, No. 3, pp. 68-74.

Magasi, C. 2016. Factors Influencing Business Succession Planning among SMEs in Tanzania. European Journal of Business and Management, Vol. 8, No. 3, pp. 126-135.

Marita Rautiainen, Lappeenranta University of Technology, Timo Pihkala, Lappeenranta University of Technology, Markku Ikävalko. 2012. Family Business System Models - A Case Study and Some Implications of Open Systems Persp. Journal of Small Business and Entrepreneurship, 25.2, pp. $155-168$. 
Review of Management and Entrepreneurship

Volume 03, Number 02, October 2019

Mattias Norqvist, Karl Wennberg, Karin Hellerstedt et al. 2013. An Entrepreneurial Process Perspective on Succession in Family Firms. Small Business Economics, Vol 40, Issue 4, p 1087-1122. 